\title{
Tebukonazol hatóanyag-tartalmú gombaölő szer és ólom-acetát együttes hatásának teratológiai vizsgálata házi- tyúk embriókban
}

\author{
Szemerédy Géza ${ }^{1 *}$, Kormos Éva ${ }^{1}$, Somody Gergő ${ }^{1}$, Buda István¹, Szabó \\ Rita$^{1}$, Lehel József ${ }^{2}$, Budai Péter ${ }^{1}$
}

1Pannon Egyetem, Georgikon Kar, Növényvédelmi Intézet, 8360 Keszthely, Deák F. u. 16.;

2Állatorvostudományi Egyetem, Élelmiszer-higiéniai Tanszék, 1078 Budapest, István u. 2.

ABSTRACT - Teratogenicity test of individual and combined toxic effects of tebuconazole fungicide and lead-acetate on chicken embryos

Author(s): Géza Szemerédy ${ }^{1}$, Éva Kormos ${ }^{1}$, Gergő Somody $^{1}$, Rita Szabó ${ }^{1}$, József Lehel ${ }^{2}$, Péter Budai ${ }^{1}$ Affiliation(s): ${ }^{1}$ University of Pannonia, Georgikon Faculty, Institute of Plant Protection, H-8360 Keszthely Deák F. str. 16. Hungary; ${ }^{2}$ University of Veterinary Medicine, Department of Food Hygiene, H-1078 Budapest, István str. 2.

The aim of this study was to determine the individual and combined toxic effects of MYSTIC 250 EC fungicide (tebuconazole $250 \mathrm{~g} / \mathrm{l}$ ) and lead acetate on the development of chicken embryos. The chicken eggs were dipped in the solution or emulsion of the test materials for 30 minutes on the first day of incubation (day 0). The applied concentrations of lead acetate were $0.01 \%$ and of fungicide MYSTIC $250 \mathrm{EC}$ was $0.1 \%$ corresponding to plant protection practice. The chicken embryos were examined on day 19 by the followings: rate of embryo mortality, body weight, type of developmental anomalies by macroscopic examination. The body weight was evaluated statistically by the one-way ANOVA with Tukey Dunnett post-test, the embryo mortality and the developmental anomalies were analyzed by Fisher test. Our teratogenicity study revealed that the combined administration of lead acetate and tebuconazole containing fungicide formulation (MYSTIC 250 EC) caused a significant reduction in body weight of embryos and increased the rate of embryonic mortality in both of applied group. The joint toxic effect of lead acetate and MYSTIC 250 EC is an additive effect compared to the individual toxicity of the test materials.

Keywords: tebuconazole, lead acetate, interaction, embryotoxicity, teratology

\section{ÖSSZEFOGLALÁS}

Vizsgálatunk arra irányult, hogy a növényvédelemben széles körben alkalmazott tebukonazol hatóanyagú MYSTIC 250 EC gombaölő szer és egy környezetszennyező nehézfém, az ólom-acetát egyedi és együttes méreghatását tanulmányozzuk házityúk-embriókban. A toxikológiai vizsgálat során kísérleti anyagként 0,01\%-os ólom-acetát oldatot, valamint a MYSTIC 250 EC (250 g/l tebukonazol) 0,1\%-os, a forgalmazó által ajánlott emulzióját alkalmaztuk. A bemerítéses kezelést a keltetés megkezdése előtt, míg a tojások feldolgozását

\footnotetext{
*CORRESPONDING AUTHOR

Pannon Egyetem, Georgikon Kar, Növényvédelmi Intézet

$\triangle 8360$ Keszthely, Deák F. u. 16., 贯 +36-83-545-226, Fax: 36-83-545-212

E-mail: tijsvanvervest@gmail.com
} 
a várható kelés előtt 2 nappal, a keltetés 19. napján végeztük el. A kórbonctani vizsgálat során lemértük az embriók testtömegét, feljegyeztük az elhalások számát, továbbá rögzítettük a makroszkópos fejlődési rendellenességeket. Statisztikai értékelésnél az élő embriók testtömegeinek összehasonlításához egytényezős varianciaanalízist (One-way ANOVA), az elhalások és a fejlődési rendellenességek számának elemzéséhez Fischer-féle egzakt tesztet alkalmaztunk. A vizsgálati anyagokkal elvégzett egyedi és együttes kezelések eredményeként a kezelt csoportokban az embriók testtömeg értékei szignifikánsan kisebbek voltak a kontroll csoporthoz viszonyítva. Az egyedi és együttes kezelések következtében jelentkező embrióletalitás - a fungiciddel egyedileg kezelt csoport kivételével - szignifikánsan emelkedett a kontroll csoporthoz képest. A fejlődési rendellenességek sporadikusan fordultak elő a kezelt csoportokban, teratogén hatás nem volt igazolható. Kísérletünkben felhasznált 0,01\%-os ólom-acetát oldat és MYSTIC 250 EC fungicid 0,1\%-os emulziójának egyedi méreghatása toxikus volt a tojásban fejlődő házityúk-embriókra nézve. A kísérleti anyagok együttes alkalmazása során az embriótoxikus dózisú ólomacetát mellett a növényvédelmi gyakorlatban felhasznált MYSTIC 250 EC gombaölő szeres kezelés fokozta az embriótoxicitást, a toxikus interakció additív jellegű volt.

(Kulcsszavak: tebukonazol, ólom-acetát, interakció, embriótoxicitás, teratológia)

\section{BEVEZETÉS}

Folyamatosan fejlődő világunk egyik legnagyobb problémája a növekvő népesség számára megfelelő mennyiségű és minőségű élelmiszer előállítása. A XX. században megkezdődött az agrárium kemizálása, melynek következtében egyre nagyobb mértékben használták a piacra berobbant, veszélytelennek hitt növényvédő szereket. A mezőgazdasági termelésen belül a kémiai növényvédelem tekinthető az egyik leginkább környezetszennyező területnek. A vegyszeres növényvédelmi munkák során felhasznált növényvédő szerek elsősorban a kijuttatás területén, de onnan távolabbra elsodródva a nem célszervezeteken is kifejthetik hatásaikat, amelynek következtében a keltetés időszakában a vadon élő madarak tojásaira kerülő permetléből bejutó hatóanyag megzavarhatja az embriók fejlődését (Fejes, 2005). A tojásba bejutó testidegen kémiai anyag mennyiségét döntően befolyásolhatja a tojások meszes héjának áteresztő-képessége. Ugyanakkor, nagymértékben függ a tojáshéj-képződéskor jelenlévő környezeti tényezőktől is, amelynek következtében az ugyanazon egyedtől származó, egymást követő tojások mészhéj-porozitása is eltérő lehet 
(Tullett és Deeming, 1982; Tyler, 1955). Azt is figyelembe kell vennünk a különböző xenobiotikumok toxikológia vizsgálatakor, hogy az egyes anyagok döntő részben külön-külön kerülnek alkalmazásra. Azonban az egyidejűleg jelen lévő vegyi anyagok egymás mérgező hatását befolyásolhatják, és ezáltal jelentősen megváltozik az összességében kifejtett hatás (Várnagy, 1995). A madárteratológiai vizsgálatok során alkalmazott bemerítéses kezelés lehetővé teszi a madárembrióra gyakorolt indirekt hatások tanulmányozását, és így megfelelően modellezi a környezetben érvényesülő egyedi és interakciós károsító hatásokat (Lutz és Oterag, 1973; Hoffman és Gay, 1981).

Vizsgálatunkban egy tebukonazol hatóanyagú fungicid (MYSTIC 250 EC) és a környezeti fémterhelést modellező ólom-acetát egyedi és együttes méreghatását vizsgáltuk a tojásban fejlődő házityúk-embriókban annak igazolása érdekében, hogy a vegyi anyagok természetes körülmények között érvényesülő expozíciója embriótoxikus hatású lehet-e. Bár az elmúlt évtizedekben több olyan publikáció is megjelent az alapkutatás szintjén, amelyben különböző vegyi anyagok együttes károsító hatását vizsgálták, mind madár, mind hal szervezeteken. Az engedélyezési gyakorlatban használatos ökotoxikológiai vizsgálati módszerek elsősorban csak az egyedi méreghatás vizsgálatára szorítkoznak, ezért a növényvédő szerek interakciós hatásaira vonatkozó adatok segítségével alaposabban megismerhetőek a környezeti vegyi anyag expozíciók káros következményei.

\section{ANYAG ÉS MÓDSZER}

A környezeti ólomterhelés modellezéséhez az egyedi és együttes kezelések során 0,01\%-os koncentrációjú ólom-acetát oldatot (Reanel-Ker Kft., Magyarország) alkalmaztunk, amelyet egy elővizsgálat eredményei alapján választottunk ki. Ennek során az ólom-acetát 1\%, 0,1\% és 0,01\% koncentrációjú oldatainak embriótoxikus hatását tanulmányoztuk, hogy kiválasszuk azt a legalacsonyabb dózist, amely az interakciós vizsgálatban csak kismértékű embriótoxicitást mutat. A legalacsonyabb koncentráció $(0,01 \%)$ már testtömeg-csökkenést és az embriómortalitás kismértékű fokozódását eredményezte. A 0,1\%-os koncentráció esetében a testtömeg-csökkenés mellett az embriómortalitás már jelentősen fokozódott, így a 0,01\%-os koncentráció alkalmazása mellett döntöttünk. A $250 \mathrm{~g} / \mathrm{l}$ tebukonazol hatóanyagú MYSTIC 250 EC (Nufarm Hungaria Kft., Magyarország) gombaölő szer, mind az egyedi, mind a kombinációs kezelések során a gyártó által ajánlott töménységben $(0,1 \%)$ került felhasználásra. A vizsgálati anyagok oldatainak és emulzióinak elkészítéséhez, illetve a kontroll tojások kezeléséhez 0,75\%-os madárfiziológiás sóoldatot használtunk fel. A kísérletben felhasznált termékeny tyúk- 
tojások a Goldavis Kft. (Sármellék, Magyarország) vegyes hasznosítású, Farm fajtájú tenyészetéből (apai és anyai vonal Farm) származtak. A tojások keltetését RAGUS $^{\circledR}$ (Wien, Ausztria) típusú asztali keltetőgépben végeztük. A keltetés ideje alatt gondoskodtunk a megfelelő hőmérsékletről $\left(37-38^{\circ} \mathrm{C}\right)$, a páratartalomról (65$75 \%$ ) és a tojások naponta történő többszöri forgatásáról. A tyúktojásokat ( $\mathrm{n}=40 /$ csoport) a keltetés megkezdése előtt a vizsgálati anyagokból készült $37^{\circ} \mathrm{C}$ os hőmérsékletű oldatokba és emulziókba, valamint azok kombinációjába helyeztük 30 perces időtartamra, majd a folyadék lecsepegtetése után behelyeztük azokat a keltetőgépbe, és beindítottuk a keltetést. A várható kelés előtt 2 nappal, a 19. napon került sor a tojások feldolgozására. A kórbonctani feldolgozás során jegyzőkönyvben rögzítettük az élő embriók testtömegét, az elhalt embriók számát és az élő embriókon megfigyelt makroszkópos deformitásokat. Az élő embriók testtömeg adatainak eloszlását grafikusan Comparison-QuantilePlot-tal ellenőriztük, majd a statisztikai értékelést egytényezős varianciaanalízissel (One-Way ANOVA) végeztük. Az embriómortali-tási adatok és a fejlődési rendellenességek biometriai értékeléséhez a Fisher-féle egzakt tesztet alkalmaztuk (Baráth és mtsai, 1996). A statisztikai értékelés során a szignifikancia minimum értékének a $\mathrm{p}<0,05$ szintet tekintettük.

\section{EREDMÉNYEK ÉS ÉRTÉKELÉSÜK}

A fejlődési rendellenességek és az embrió elhalások számának és arányának alakulását az 1. táblázatban tüntettük fel.

\section{1. táblázat}

A fejlődési rendellenességek és az embrió elhalások számának és arányának alakulása tebukonazol hatóanyagú MYSTIC 250 EC és ólom-acetát bemerítéses kezeléssel elvégzett madárteratológiai vizsgálatában

\begin{tabular}{lcccc}
\hline & \multicolumn{2}{c}{ db } & \multicolumn{2}{c}{$\%$} \\
Kezelt csoportok & $\begin{array}{c}\text { Rendellenes fej- } \\
\text { lődésú embriók } \\
\text { száma/élő emb- } \\
\text { riók száma }\end{array}$ & $\begin{array}{c}\text { Elpusztult emb- } \\
\text { riók száma/ter- } \\
\text { mékeny tojások } \\
\text { száma }\end{array}$ & $\begin{array}{c}\text { Rendellenes } \\
\text { fejlődésű emb- } \\
\text { riók aránya }\end{array}$ & $\begin{array}{c}\text { Elpusztult } \\
\text { embriók ará- } \\
\text { nya }\end{array}$ \\
\hline Kontroll & $0 / 37$ & $1 / 38$ & 0 & 2,6 \\
Ólom-acetát & $3 / 30$ & $8 / 38^{\mathrm{a}}$ & 10 & 21,05 \\
MYSTIC 250 EC & $1 / 37$ & $1 / 38$ & 2,7 & 2,6 \\
MYSTIC 250 EC + & $3 / 31$ & $7 / 38^{\mathrm{a}}$ & 9,67 & 18,42 \\
Ólom-acetát & & & & \\
\hline
\end{tabular}

a Szignifikáns eltérés a kontroll csoporthoz viszonyítva $(\mathrm{p}<0,05)$

Table 1 Embryonic death and developmental anomalies from teratogenicity test of lead acetate and Mystic 250 EC in chicken embryos after single and combined administration by an immersion technique; a Significant difference as compared to the control $(p<0,05)$ 


\section{Kontroll csoport eredményei}

A madárfiziológiás $\mathrm{NaCl}$ oldattal kezelt csoportban az embriók testtömege $20,30 \pm 1,28$ g volt. A kontroll csoportban egy embrió pusztult el, így a termékeny tojások számához viszonyítva az elhalt embriók aránya $2,6 \%$ volt. Fejlődési rendellenességet mutató embrió nem fordult elő, ami lehetővé tette a csoport viszonyítási alapként való alkalmazását.

\section{ólom-acetátos kezelés eredményei}

Az ólom-acetát 0,01\% koncentrációjú oldatával elvégzett egyedi bemerítéses kezelés eredményeként az embriók testtömeg értéke $(19,51 \pm 1,11 \mathrm{~g})$ szignifikánsan $(\mathrm{p}<0,05)$ kisebb volt a kontroll csoport értékéhez $(20,30 \pm 1,28 \mathrm{~g})$ viszonyítva (1. ábra). A 0,01\%-os ólom-acetát oldatába merített kezelés hatására 8 embrió halt el, az elpusztult embriók aránya (21\%), ami szignifikánsan magasabb volt $(\mathrm{p}<0,05)$ a kontroll csoportban megfigyelt elhalás mértékéhez $(2,6 \%)$ képest. A nehézfémmel kezelt embriók közül 3 embrió is károsodott a fejlődésben. Mindhárom egyeden deformálódott lábakat figyeltünk meg

\section{MYSTIC 250 EC kezelés eredményei}

A tebukonazol hatóanyagú MYSTIC 250 EC egyedi toxicitásának vizsgálatakor a gombaölő szert 0,1\%-os a növényvédelemben ajánlott gyakorlati permetlé töménységben alkalmazva azt tapasztaltuk, hogy a kezelés hatására a madárembriók testtömege $(19,32 \pm 1,40$ g) szignifikánsan kisebb volt kontroll csoport adataihoz viszonyítva $(20,30 \pm 1,28 \mathrm{~g} ; \mathrm{p}<0,01)$. A fungiciddel egyedileg kezelt csoportban egy embrió pusztult el, az embriómortalitás aránya 2,6\% volt. A növényvédő szerrel kezelt csoport élő embriói között egy esetben figyeltünk meg fejlődési rendellenességet, típusa görbült láb volt

\section{Ólom-acetát és MYSTIC 250 EC együttes kezelés eredményei}

A 0,01\%-os ólom-acetáttal és a MYSTIC 250 EC 0,1\%-os koncentrációjú emulziójával elvégzett együttes kezelés eredményeként szignifikáns mértékben ( $\mathrm{p}<0,001)$ csökkent az élő embriók testtömege $(18,48 \pm 1,22$ g) a kontroll csoportban mért értékekhez $(20,30 \pm 1,28$ g) viszonyítva. Szintén csökkenő tendencia volt tapasztalható a vizsgálati anyagok egyedi kezeléseihez képest, amely az ólom-acetáttal egyedileg kezelt csoport testtömeg értékei $(19,51 \pm 1,11$ g) esetében 5,6\%-os eltérés, míg a tebukonazol hatóanyagú MYSTIC 250 EC kezelt csoport testtömeg értékei (19,32 $\pm 1,40$ g) esetében 4,5\% mértékben nyilvánult meg (1. ábra). Az ólom-acetáttal és gombaölő szerrel történt együttes kezelés hatására 7 embrió halt el, az elpusztult embriók aránya $(18,4 \%)$ a kontroll csoporthoz viszonyítva $(2,6 \%)$, a különbség szignifi- 
káns volt $(\mathrm{p}<0,05)$. Az ólom-acetáttal és a fungiciddel együttesen kezelt csoportban 3 élő embrión jelentkezett deformáció, amelynek típusa lábgörbülés volt. A kezelések hatására ugyan növekedett a fejlődési rendellenességek gyakorisága, de a változás sem az egyedileg, sem az együttesen kezelt csoportban nem volt statisztikailag igazolható a kontroll csoporthoz viszonyítva.

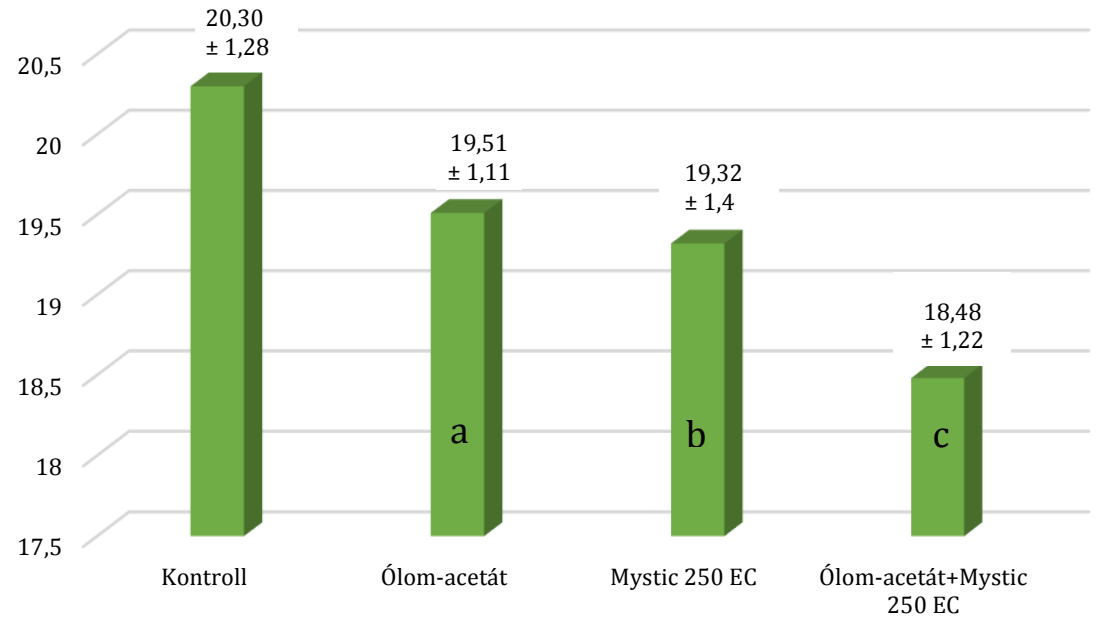

$a=$ szignifikáns eltérés a kontroll csoporthoz képest $(p<0,05)$; b= szignifikáns eltérés a kontroll csoporthoz képest $(\mathrm{p}<0,01)$; $\mathrm{c}=$ szignifikáns eltérés a kontroll csoporthoz képest $(\mathrm{p}<0,001)$.

1. ábra: Embrionális testtömeg adatok alakulása (g) a tebukonazol hatóanyagú MYSTIC 250 EC és az ólom-acetát bemerítéses kezeléssel elvégzett egyedi és együttes méreghatásának madárteratológiai vizsgálatában.

Figure 1. Body weight (g) of the chicken embryos on day 19 of incubation from teratogenicity test on Mystic 250 EC and lead acetate after single and simultaneous administration by an immersion technique. $a=$ Significance decrease as compared to the control $(p<0,05) ; b=$ Significance decrease as compared to the control $(p<0,01)$; $c=$ Significance decrease as compared to the control $(p<0,001)$

\section{KÖVETKEZTETÉSEK ÉS JAVASLATOK}

Az 0,01\%-os ólom-acetát oldattal elvégzett egyedi kezelés eredményei alapján megállapítható, hogy a kísérletben alkalmazott koncentráció embriótoxikus volt, amely szignifikáns mértékű testtömeg-csökkenésben és szignifikáns mértékben növekedett embrióelhalásban nyilvánult meg. Teratogén hatás azonban nem volt igazolható, mivel a fejlődési rendellenesség előfordulási gyakori- 
sága alacsony volt. Korábban Fejes (2000) és Juhász (2009) hasonló eredményről számolt be $0,1 \%$ és $0,01 \%$-os ólom-acetáttal elvégzett madárteratológiai vizsgálatban. A kezelések hatására a házityúk-embriók testtömege szignifikánsan csökkent, az elhalt embriók száma jelentősen növekedett, azonban fejlődési rendellenességek előfordulása sporadikus jellegűek voltak.

A Mystic 250 EC növényvédő szerrel történt kezelés hatására szignifikáns mértékủ változás csupán a testtömeg-csökkenésben nyilvánult meg, statisztikailag igazolható eltérés az embriomortalitás és a fejlődési rendellenességek esetében nem volt megfigyelhető. Giavini és Menegola (2010) a mezőgazdaságban és a humán gyógyászatban gombaölő szerként alkalmazott azol-származékok toxikológiai állatkísérleti eredményeik alapján megállapították, hogy a különböző azol típusú fungicidek nagy dózisban teratogén hatásúak, arc, csontváztengely és végtag rendellenességek kialakulását eredményezik.

A környezeti fémterhelést modellező ólom-acetát és a gombaellenes vegyszeres kezelésként használható MYSTIC 250 EC együttes hatása szintén embriótoxikusnak bizonyult, hiszen szignifikánsan csökkent az embriók testtömege, és nőtt az embriómortalitások száma, de teratogén hatást itt sem tapasztaltunk, mivel a fejlődési rendellenességek tekintetében itt sem bizonyultak statisztikailag igazoltnak az eltérések.

Az együttes méreghatás additív formában nyilvánult meg. Saját vizsgálati eredményeinkkel összhangban a növényvédő szerek kombinációi általában fokozzák, sőt egyes esetekben akár jelentősen növelhetik az összetevők méreghatását, ezáltal természetesen felhasználásuk is kockázatos. Ezek a hatások faj, idő-, illetve dózisfüggőek, ezért meglehetősen nehéz előre jelezni a potenciális károsító hatást (Thompson 1996).

A környezetszennyező nehézfémek és növényvédő szerek egyedi és együttes hatásainak madárteratológiai vizsgálataiból származó eredmények értékelése nagyban hozzásegíthet ahhoz, hogy a környezeti élőszervezetek védelmét a lehető legmagasabb szinten tudjuk biztosítani.

\section{KöSZÖNETNYILVÁNÍTÁS}

A publikáció elkészítését az EFOP-3.6.3-VEKOP-16-2017-00008 számú projekt támogatta. A projekt az Európai Unió támogatásával, az Európai Szociális Alap társfinanszírozásával valósult meg.

\section{IRODALOM}

Baráth Cs., Ittzés A. és Ugrósdy Gy. (1996): Biometria. Mezőgazda Kiadó, Budapest. 37-217. 
Fejes S. (2000): Az ólom-acetát és DITHANE M-45 együttes toxicitásának vizsgálata házityúk embrión. Diplomadolgozat. Veszprémi Egyetem, Keszthely. 15-25.

Fejes S. (2005): Egyes nehézfémek és növényvédő szerek egyedi és együttes méreghatásának vizsgálata madárteratológiai tesztben, Doktori Értekezés, Veszprémi Egyetem, Keszthely. 83-84.

Giavini E., Menegola E. (2010): Are azole fungicides a teratogenic risk for human conceptus? Toxicology Letters, 198(2): 106-111. DOI: 10.1016/j.toxlet.2010.07.005

Hoffmann D. J., Gay M. L. (1981): Embryotoxic effect of benzo(a)pyrene, chrysene and 7,12dimethylbenz(a) anthrance in petroleum hydrocarbon mixtures in mallard ducks. J. Toxicol. Environ. Hlth., 7(5):775-787. DOI: 10.1080/15287398109530019

Juhász É. (2009): Herbicidek (Stomp 330 EC, Dikamin D) és nehézfémek (Réz, Kadmium, Ólom) egyedi és együttes méreghatása madárembriókon, Doktori Értekezés, Pannon Egyetem, Keszthely. 130131.

Lutz H., Oterag Y. (1973):Pesticides teratogenese et surricchez les oiseaux. Arch. Anat. Hist. Embr., 56:65-68.

Thompson H. M. (1996): Interaction between pesticides; A review of reported effects and their implications for wildlife risk assessment. Ecotoxicology, 5(2): 59-81. DOI: $10.1007 / \mathrm{bf00119047}$

Tullett S. G., Deeming D. C. (1982): The relationship between egg shell porosity and oxygen consumption of the embryo in domestic fowl. Comp. Biochem. Physiol. Part A, 72(3): 529-533. DOI: 10.1016/0300-9629(82)90118-9

Tyler C. (1955): Studies on egg shells. VI. - The distribution of pores in egg shell. J. Sci. Food. Agric., 6(3): 170-176. DOI: $10.1002 /$ isfa.2740060310

Várnagy L. (1995): Teratogenicity testing of pesticides on bird fetuses. Hung. Agr. Res., 2:30-33. 